\title{
Higher estimation, lower harvesting: case of NTFPs from Dhaulagiri region, Nepal
}

\author{
G. Paudel ${ }^{1 *}$ and R. Acharya ${ }^{2}$
}

In Nepal, non-timber forest products (NTFPs) have high potentiality in contributing to local and national economy. Studies have shown that the potentiality of NTFPs has not been realized yet. This paper aims to explore the number of NTFPs species and quantity collected against the number of NTFPs species and quantity specified in the five year forest management plans of three districts (Baglung, Parbat and Myagdi) in Dhaulagiri region. The data related to number of NTFPs species and the quantity collected in fiscal year 2016/2017 were acquired from three District Forest Offices (Baglung, Parbat and Myagdi) and compared them as specified in the five year forest management plans. The NTFPs species specified for collection in the plans were 90 in Baglung, 50 in Myagdi and 13 in Parbat district. Only 21 species from Baglung, 16 species from Myagdi and none species from Parbat were collected in fiscal year $2016 / 2017$. The annual total quantity of the NTFPs specified in the plans of three districts was 454.21 tons with the royalty of US\$78,500. But the harvested quantity of NTFPs was only 31.18 tons with the royalty of US\$ 4,610 in fiscal year 2016/2017. The quantity of harvested NTFPs was $9.59 \%$ and $3.64 \%$ of their supply potential in Baglung and Myagdi districts, respectively, while there was no collection of NTFPs from Parbat district. On an average, only $6.87 \%$ of NTFPs specified in the plans were collected, generating only $5.87 \%$ of the total royalty specified in the plans. The study revealed that remoteness of the area, lower quantity of NTFPs for commercial harvesting and lack of site specific plan of NTFPs are the major causes for under harvesting. Networking of local people and NTFPs traders and formulating site and species specific NTFPs conservation, management and utilization plan are necessary to collect NTFPs in a sustainable manner from these districts.

Key words: Allowable harvest, extraction, management, potentiality, under harvesting

$\mathrm{H}$ arvesting of Non-Timber Forest Products (NTFPs) has been a long history in the human civilization (Delgado, 2016). Nepal's NTFPs are harvested from ancient time due to their medicinal values and other livelihood activities largely in the subsistence form rather than in the commercial scale. People have been using NTFPs as medicine. Till 1980s, the timber dominated in the forestry considering it as the only commercially viable forest product. The value of NTFPs came into surface when a group of scientists estimated the higher value of the NTFPs than that of the timber. Peters et al. (1989) estimated higher value of NTFPs than timber even in the Amazonian rainforest and after that the forest policies started worldwide to emphasise the NTFPs as the important forest product (Banjade and Paudel, 2008). NTFPs have significantly lower life span than the timber (Lawrence, 2003) so that it could be the product of comparative advantage in the forestry sector. Low volume high value of NTFPs as compared to the high volume low value in case of the timber makes the NTFPs as the product of comparative advantage from forest.

Diverse geography and climatic conditions result in richness of biodiversity in Nepal. The recorded floral species are 11,971 in Nepal, which constitutes $3.2 \%$ of the world's total flora

\footnotetext{
1 Department of Forests and Soil Conservation, Babarmahal, Kathmandu, Nepal

* E-mail: ecopaudel@gmail.com

2 Department of National Parks and Wildlife Conservation, Nepal
} 
(GoN, 2014). The plant species found in Nepal have different medicinal values. Over 1000 plant species have known uses, of which over 700 species are medicinal plants, 440 wild foods, 30 spices and other 71 fibre yielding (Subedi et al., 2014). The sustainable utilization of highly diverse and valuable NTFPs can be the pathway of prosperity for Nepali people. Although Nepal is rich in bio resources and famous in some forest management approaches notable community forestry (Paudel, 2014; Paudel, 2015) harnessing its potentiality to contribute to the national economic development remains always lacking. Likewise all forest products, NTFPs sector in Nepal is lagging behind to significantly contribute to the local and national economy. Banjade (2012) stated that it is due to the fact that forestry sector in Nepal is not harnessing its full potential.

In the changing international context, Nepal has given emphasis to the NTFPs through formulation and implementation of various policies and legislations (Banjade and Paudel, 2008). On the one hand, ppolicies related to NTFPs promotion and field reality is different and on the other hand implemented policies do not harmonize with the policy objectives in Nepal (Larson et al., 2000). Recently scholars try to help for systematizing the NTFPs cultivation and harvesting by formulating locally suited criteria and indicators of NTFPs certification (Paudel et al., 2018). These initiatives are yet to be approved from government and still the transaction cost is high especially due to poor governance and corruption in trading of forest products (Subedi et al., 2014) which led to the under utilization of the forest product. Value chain of the NTFPs involves different stakeholders viz. small scale harvesters, local traders, transporters, exporters and consumers (Ingram et al., 2012). Inappropriate policy and legal framework are creating hurdles in collection and trading of timber and NTFPs locally (Baral et al., 2016). In case of NTFPs in Nepal, over-exploitation of resource was perceived without any qualitative studies on ecological condition of the NTFPs (Larsen et al., 2000). Nepal's NTFPs are thought as over-exploited considering them as the open access property but in fact Nepal's NTFPs are not open access resources (DoF, 2017) and managed by local communities and government under the legal framework. Under utilization of the resources has been discussed less than over exploitation of resources but due to lack of quantitative assessment of the NTFPs, the actual status of NTFPs is still unknown in many forests of Nepal.

Forest Act, 1993 stipulates the preparation of five year forest management plan of the district by Department of Forests which should be approved from the Ministry of Forests and Soil Conservation. This management plan then should be implemented by the District Forest office (DFO). This provision has been changed and now the responsibility of preparing and implementing the management plan is through DFO and the Department has the authority to approve the management plan submitted by the DFO. The management plan is one of the guiding documents for harvesting forest products including NTFPs from the national forests. It is a technical as well as legal document, which the DFO has to follow both to carry out the technical and other works. DFO has the right to grant permission to conduct work specified in the five year forest management plan. DFO can provide license to collect the forest products including NTFPs not exceeding the quantity specified in the management plan.

The quantity of NTFPs specified in the management plan denotes the supply potential of the NTFPs from the district. Generally that value was considered to highlight the importance of NTFPs in income generation and contribution to the local as well as national economy. Actual collection of NTFPs from the district could be different than the quantity specified in the management plan. Unsustainable exploitation of the NTFPs has been observed in various places while in some places there is little extraction of NTFPs as compared to their potentiality. Researches regarding the actual extraction of forest products including NTFPs in line with the quantity specified in the forest management plan is lacking in Nepal. In this context, this study was carried out with the objective of analysing the collection status of the NTFPs as compared to their supply potential specified in the five year forest management plan. This paper also aims to explore the obstacles of the NTFPs collection in these districts.

\section{Materials and methods Study area}

Dhaulagiri region consists of four districts, namely Baglung, Parbat, Myagdi and Mustang. 
This study was carried out in three districts (Baglung, Parbat and Myagdi) of this region. Mustang district was excluded from the study, as there is no District Forest Office. The latitude of Baglung district ranges from $28^{\circ} 5^{\prime} \mathrm{N}$ to $28^{\circ} 15^{\prime}$ $\mathrm{N}$ and longitude from $82^{\circ} 45^{\prime} \mathrm{E}$ to $83^{\circ} 36^{\prime} \mathrm{E}$. The area covered by the Baglung district is 182,486 hectares (DFO Baglung, 2014). Likewise, the latitude of Myagdi district varies from 28 $20^{\prime}$ $\mathrm{N}$ to $28^{\circ} 47^{\prime} \mathrm{N}$ and longitude from $83^{\circ} 08^{\prime} \mathrm{E}$ to $83^{\circ} 53^{\prime}$ longitude and the area is 229,706 ha (DFO Myagdi, 2014). Parbat district is situated between $27^{\circ} 28^{\prime} \mathrm{N}$ and $28^{\circ} 39^{\prime} \mathrm{N}$ latitude, 83 ${ }^{\circ} 34^{\prime} \mathrm{E}$ and $83^{\circ} 59^{\prime}$ E longitude and has an area of 53,668 ha (DFO Parbat, 2015). Two largest projects, Livelihoods and Forestry Program (LFP) and the Multistakeholder Forestry Program (MSFP), worked in these three districts. Investments have been made to assess resource and promote NTFPs in these districts through these projects and government fund. These districts are considered very rich in NTFPs resources. Map of the studied districts is given in figure 1.

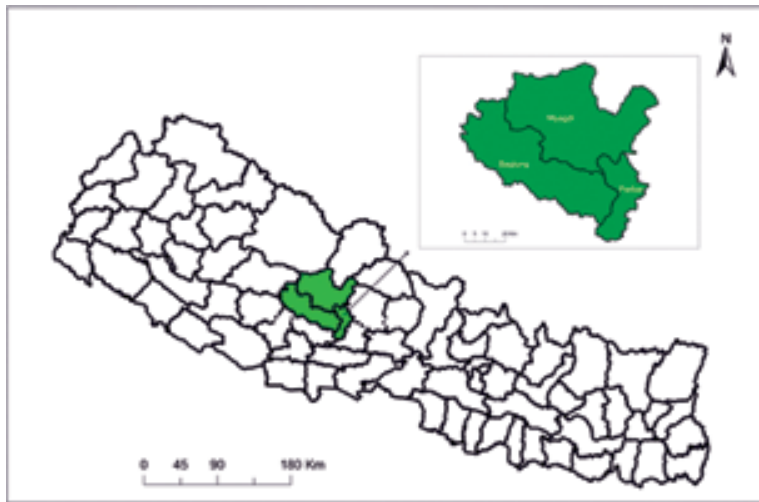

Fig. 1: Map of the studied districts

\section{Desk review}

The approved district five year forest management plans of Baglung, Myagdi and Parbat districts were reviewed. The growing stock of the NTFPs, their annual allowable harvestable quantity and the estimated royalty were recorded from these management plans. The data related to type of NTFPs species and the quantity collected in fiscal year 2016/2017 was acquired from records of the respective District Forest Offices.

\section{Consultation}

The officials of the District Forest Offices of these three districts were consulted to know about the current trend in NTFPs collection. NTFPs collectors, traders and the local people related to the NTFPs were also consulted to understand their views on the trend and obstacles in NTFPs collection in these districts.

\section{Data analysis}

The data were fed into Ms-Excel and analysed accordingly. Extracted quantity of NTFPs was compared with estimated annual allowable harvest in the five year forest management plans of the respective districts. Likewise the actual royalty was compared with the estimated royalty from NTFPs collection in the five year forest management plans.

\section{Results and discussion}

\section{Number of species}

Ninety NTFPs species were listed and the annual quantity to be collected was specified in the management plans of these three districts (Fig. 2 ). Among them less than half or only 36 NTFPs species were found to be collected ( $40 \%$ of total) in these three districts in fiscal year 2016/2017. In Baglung district, 90 NTFPs species were specified in the management plan, but only 21 species were collected in fiscal year 2016/2017. In Myagdi and Parbat districts 50 and 13 NTFPs species were specified in the management plans but only 16 species were collected in Myagdi district but none species were collected in Parbat district. Species of Myagdi and Parbat district are contained in Baglung district list and therefore total number of species is 90 in the management plan.

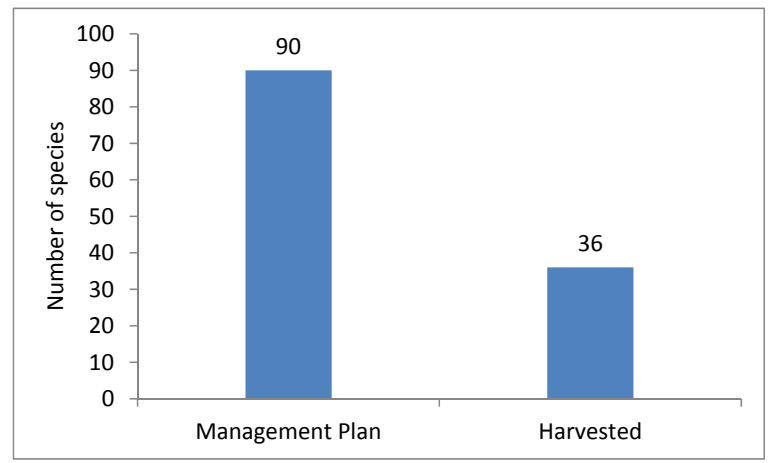

Fig. 2: Number of species specified for harvesting in management plans and actually harvested species in three districts in fiscal year 2016/2017 


\section{Quantity of NTFPs}

Five year forest management plan of the district contains information on Annual Allowable Harvest (AAH) of the NTFPs species. The quantity of NTFPs to be harvested annually from the natural forests mentioned in the plans of three districts was about 454.21 tons (265.76 tons from Baglung, 156.47 tons from Myagdi and 31.98 tons from Parbat district). The actual quantity of harvested NTFPs was only 31.18 tons in fiscal year 2016/2017 in three districts (Fig. 3), which is equal to $6.86 \%$ of the total harvestable quantity of NTFPs species specified in the management plan. The actual quantity of NTFPs collected from Baglung and Myagdi districts was 25.49 tons and 5.69 tons, respectively. But there was no collection of NTFPs from Parbat district. This revealed that the large quantity of NTFPs is remained in the forest, which is unutilized.

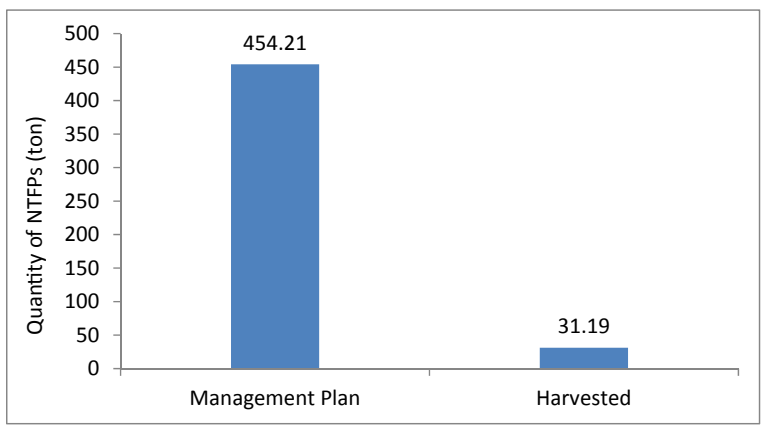

Fig. 3: Quantity of NTFPs specified in management plans of three districts and actually harvested

\section{Royalty}

The estimation of annual royalty collection from harvesting of NTFPs as stated in the management plants of three districts was $\$ 78,500$ (1US $\$=$ NRs. 100) (Fig. 4). The estimated royalty from harvesting NTFPs as stated in the plans of Baglung, Myagdi and Parbat districts was $\$ 45619.65, \$ 26150.98$ and $\$ 6729.77$, respectively. The royalties of $\$ 2806.25$ and $\$ 1808.53$ was obtained from NTFPs collection in Baglung and Myagdi districts, respectively. But no royalty was obtained in Parbat district. The total royalty of harvested NTFPs in Baglung and Myagdi districts was \$ 4610 (Fig. 4), which was only $5.88 \%$ of the estimated royalty in the plans.

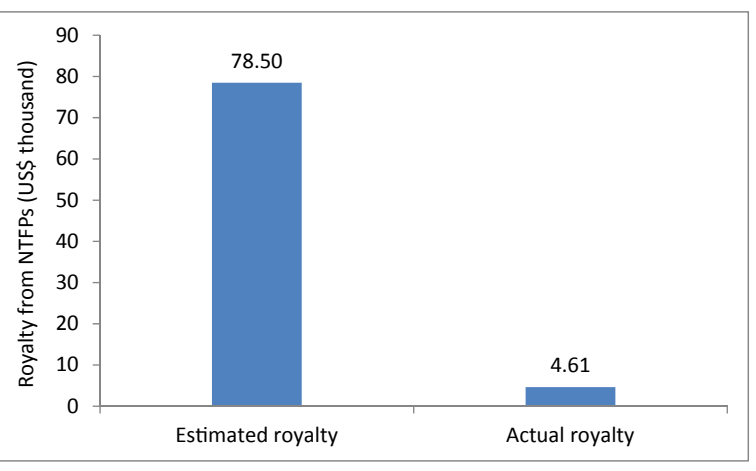

Fig. 4: Estimated royalty in the management plans and actual royalty obtained

This study showed that the NTFPs are less used as compared to their availability in the national forest. This finding is consistent with the findings of the Subedi et al. (2014). They reported that the supply potential of the NTFPs could be five times higher in the optimistic scenario and two times higher even in the conservative scenario than the current supply of the NTFPs in Nepal. The estimated royalty is higher in the management plan and thus the people judged that there could be higher contribution of NTFPs in the national economy assuming that the quantity of NTFPs specified in the official document of the District Forest Office would be collected. Among the studied high valued 10 NTFPs species, 8 species were well stocked with low level of harvesting as compared to their potential (DoF, 2017).

According to the officials of the District Forest Offices, the lower extraction of NTFPs is due to lack of commercial trading. For collectors and traders, the quantity should be considerably higher to get benefit from NTFPs collection. Availability of high valued NTFPs in remote areas was also responsible for collection of NTFPs in low quantity. Further, local traders said that the transportation cost of NTFPs collected from remote areas is too high. They also said that the low level of extraction of NTFPs is due to lack of site specific plan for NTFPs management and utilization. Local traders and even District Forest Office do not have information on availability of the NTFPs in different parts of the district. The quantity of different species was specified in the plans without indicating the forests for quantity of NTFPs to be harvested for a particular species. It has created confusion to the officials of the DFOs to grant permission for NTFPs collection, mainly for collection of a certain quantity of 
particular NTFPs to be collected from particular forest area in a sustainable manner. It indicates that the comprehensive study is needed related to the availability of NTFPs in different parts of the districts to facilitate the NTFPs collection.

Local people lack knowledge regarding commercial utilization of the NTFPs. In remote areas of the districts, they are using NTFPs for their household needs; however, NTFPs remained unutilized in many cases. Awareness creation among the local people about potentiality of the NTFPs for income generation can expedite collection and commercial trading of NTFPs. Networking of the local people and the NTFPs traders is helpful in collecting and trading the NTFPs from a particular region. Recognizing the importance of networking of local people and NTFPstraders, Department ofForests has allocated budget for establishing and strengthening the network of the local people and NTFPs traders at the district level. This programme was not found adequately implemented in these districts due to which the network was not effective. Ineffective networking of local people and the NTFPs trader lead to under utilization of the NTFPs. Due to lack of networking, traders cannot identify the NTFPs pocket area on the one hand and on the other hand local people cannot find market of NTFPs nearby them. Therefore, strengthening network of local people and traders can be helpful in sustainable utilization of the NTFPs based on their potentiality in the district.

Zivojinovic et al. (2017) identified that organizations at the national level (public and semi-public) have indirect role in NTFPs trading as they are involved only in formulation and implementation of policies for business support. The prime actor for NTFPs collection and trade is the local people in the form of collector and the traders. Government has role to formulate policies in order to utilize the NTFPs resources for income generation at local level as well as to contribute to the national economy.

The main reasons of low level collection of NTFPs in these districts are low level of awareness on NTFPs collection and lack of business orientation of local people. Subedi (2010) stated that the potentiality of forestry sector as a whole and especially NTFPs sub-sector is not tapped properly due to various reasons including remoteness of the area and other various policy issues. Little intervention from the government and the buyer's monopoly can also be attributed as the cause of lower extraction of NTFPs (Banjade and Paudel, 2012). High transaction cost to acquire collection and trade permit may lower the rate of NTFPs collection and trade complying with the regulations (Foundjem-Tita et al., 2014). In Nepal, license of the NTFPs collection should be obtained at first from the District Forest Office for trading of the NTFPs. After collecting the NTFPs not exceeding the quantity specified in the license, traders should get transportation permit of the specified quantity of permitted NTFPs species. Traders identified the cumbersome process of NTFPs collection and trade as main causes of demotivating NTFPs collectors.

The official record in DFO Parbat showed that there was no collection of NTFPs in fiscal year 2016/2017. Based on the discussion with the officials of the District Forest Office, Parbat and other stakeholders, it was known that there was no extraction of NTFPs in previous fiscal years also. The northern part of the Parbat district is rich in NTFPs resources. The local people of that area suspected that the NTFPs collected from that part of the Parbat district could be mixed with the NTFPs collected from Baglung and Myagdi districts in order to reduce cumbersome official process and transaction cost.

Low production amount, difficulty and expensive transportation and large number of actors involved in the collection and trading process increase the transaction cost of NTFPs (Baral et al., 2016) which lead to the under utilization of the NTFPs. Trade of the NTFPs in many cases takes place through informal market which underestimates the contribution of NTFPs in economy and gets low attention in policy formulation (Shackleton and Pandey, 2014). Low level of extraction in one place may lead to over exploitation of NTFPs in other places to meet the demand of market. If we ensure harvesting of the NTFPs in a sustainable manner in these districts, then there will be little chance of resource degradation. Untapped potentiality of NTFPs is both technical and governance problem. The problem of governance can be improved after having the technical information. Problem is also associated with the unrealistic management plan. Preparation of field based district forest management plan could 
help to harvest the specified quantity of NTFPs in the plan. Technical problem is that there are no scientific studies regarding the availability and supply potential of different NTFPs species in different parts of the district. Therefore the study should be conducted to estimate the supply potential of the NTFPs from different parts of the district. After conducting the study, site and species specific plan for the NTFPs management and utilization should be prepared to ensure the better utilization of NTFPs resources based on their supply potential at the district level.

\section{Conclusion}

We conclude that the lower quantity of the NTFPs has been harvested from the national forests in comparison to the quantity specified in the management plans. Due to under harvesting of NTFPs, the collected amount of the royalty is low. The identified main causes related to low level of extraction of NTFPs in comparison to their potentiality and availability are remoteness, lower amount of NTFPs, expensive transportation and high transaction cost and lack of site-specific plan of NTFPs. Networking of local people and NTFPs traders can be helpful for collection of NTFPs from different parts of the forest and therefore it is deemed necessary to strengthen the networks of local people and NTFPs traders. Formulation of site and species specific plans for the conservation, management and utilization of the NTFPs resources is recommended.

\section{References}

Banjade, M. R. 2012. Discourse and discursive practices over timber in Nepal. Journal of Forest and Livelihood 10 (1): 58-73.

Banjade, M. R. and Paudel, N. S. 2008. Economic potential of non-timber forest products in Nepal: myth or reality. Journal of forest and Livelihood 7 (1): 36-48.

Baral, S., Khanal, R., Malla, Y., Bolin, A., Buffle, P., Pathak, B. and Poudel, J. 2016. Increasing Private Sector Involvement and Investment in Forestry in Nepal. The International Institute for Environment and Development (IIED) Policy Brief April, 2016.
Delgado, T. S., McCall, M. K. and López-Binqüist, C. 2016. Recognized but not supported: Assessing the incorporation of nontimber forest products into Mexican forest policy. Forest Policy and Economics 71: 36-42.

DFO Baglung. 2014. District Five Year Forest Management Plan. District Forest Office, Baglung, Nepal.

DFO Myagdi. 2014. District Five Year Forest Management Plan. District Forest Office, Myagdi, Nepal.

DFO Parbat. 2015. District Five Year Forest Management Plan. District Forest Office, Parbat, Nepal.

DoF. 2017. Status Study/Mapping of Important Medicinal and Aromatic Plants (MAPs) of Nepal and Preparation of Document for Jadibuti Program. Department of Forests, Kathmandu, Nepal.

Foundjem-Tita, D., Speelman, S., D'Haese, M., Degrande, A., Van Huylenbroeck, G., Van Damme, P. and Tchoundjeu, Z. 2014. A tale of transaction costs and forest law compliance: Trade permits for Non Timber Forests Products in Cameroon. Forest Policy and Economics 38: 132-142.

GoN. 2014. Nepal National Biodiversity Strategy and Action Plan (NBSAP) (2014-2020). Ministry of Forests and Soil Conservation, Singh Durbar, Kathmandu Nepal.

Ingram, V., Ndumbe, L. N. and Ewane, M. E. 2012. Small scale, high value: Gnetumafricanum and buchholzianum value chains in Cameroon. Small-scale forestry 11 (4): 539-56.

Larsen, H. O., Olsen, C. S. and Boon, T.E. 2000. The non-timber forest policy process in Nepal: actors, objectives and power. Forest Policy and Economics 1: 267-281.

Lawrence, A. 2003. No forest without timber? International Forestry Review 5 (2): 87-96. 
Paudel, G. 2014. Analysis of equity, poverty and sustainability aspects of community forests of Nepal. VIKAS 36 (1): 89-96.

Paudel, G. 2015. Forest resource income variation in mid-hills of Nepal: a case study from two CFUGs of Parbat district, Nepal. International Journal of Environment 4 (3): 1-10.

Paudel, G., Shrestha, T. K., Baniya, C. B., Lamsal, R. P., Baral, S. R., Kandel, D. L., Kalikote, B. B., Shrestha, M. and Parajuli, A. 2018. Local criteria and indicators for non-timber forest products certification in Nepal. International Journal of Forestry and Horticulture 4 (3): 25-32.

Peters, C. M., Gentry, A. H. and Mendelsohn, R.O. 1989. Valuation of an Amazonian rainforest. Nature 339 (6227): 655-656.

Shackleton, C. M. and Pandey, A. K. 2014. Positioning non-timber forest products on the development agenda. Forest Policy and Economics 38: 1-7.
Subedi, B. P. 2010. "Policy and Regulatory Environment for the Conservation and Sustainable use of NTFPs in Nepal" Paper presented at the PROFOR-World Bank Nepal Forest Sector Review Project Workshop, Kathmandu, Nepal.

Subedi, B. P., Ghimire, P. L., Koontz, A., Khanal, S. C., Katwal, P., Sthapit, K. R. and Mishra, S. K. 2014. Private Sector Involvement and Investment in Nepal's Forestry: Status, Prospects and Way Forward. Multi Stakeholder Forestry Programme (MSFP)Service Support Unit, Babarmahal, Kathmandu, Nepal.

Zivojinovic, I., Nedeljkovic, J., Stojanovski, V., Japelj, A., Nonic, D., Weiss, G. and Ludvig, A. 2017. Non-timber forest products in transition economies: Innovation cases in selected SEE countries. Forest Policy and Economics 81: 18-29. 